®М. О. Щербина, В. В. Лазуренко, А. О. Щедров

Харківський начіональний медичний університет

\title{
СУЧАСНІ ПІДХОДИ ДО ЛІКУВАННЯ УСКЛАДНЕНЬ ВАГІТНОСТІ ПІСЛЯ ЗАСТОСУВАННЯ ДРТ
}

\begin{abstract}
СУЧАСНІ ПІДХОДИ ДО ЛІКУВАННЯ УСКЛАДНЕНЬ ВАГІТНОСТІ ПІСЛЯ ЗАСТОСУВАННЯ ДРТ. У роботі досліджені механізми розвитку ускладнень вагітності після застосування ДРТ. Доведено, що ускладнення виникають на фоні імунологічних розладів, гормонального дисбалансу, гемодинамічних порушень та ендотеліальної дисфункції. Запропонована комплексна терапія дозволяє в короткі терміни нормалізувати імунологічні реакції, блокувати процеси ендотеліальної дисфункції, виявляє високу ефективність у лікуванні та профілактиці ускладнень вагітності, яка наступила після використання ДРТ.
\end{abstract}

СОВРЕМЕННЫЕ ПОДХОДЫ К ЛЕЧЕНИЮ ОСЛОЖНЕНИЙ БЕРЕМЕННОСТИ ПОСЛЕ ПРИМЕНЕНИЯ ВРТ. В РАбОТР исследованы механизмы развития осложнений беременности после применения ВРТ. Доказано, что осложнения возникают на фоне иммунологических нарушений, гормонального дисбаланса, гемодинамических расстройств и эндотелиальной дисфункции. Предложенная комплексная терапия позволяет в короткий срок нормализовать иммунологические реакции, блокировать процессы эндотелиальной дисфункции, демонстрирует высокую эффективность в лечении и профилактике осложнений беременности, наступившей в результате использования ВРТ.

MODERN APPROACHES TO THE TREATMENT OF PREGNANCY COMPLICATIONS AFTER ART. The mechanisms of pregnancy complications after the use of ART were studied. It is proved that complications arise against immunological disorders, hormonal dysbalances, hemodynamic disorders and endothelial dysfunction. The proposed complex therapy allows a short time to normalize immunological reactions, to block the processes of endothelial dysfunction, shows high efficacy in the treatment and prevention of complications of pregnancy, resulting from the use of ART.

Ключові слова: ускладнення вагітності, допоміжні репродуктивні технології (ДРТ), озонотерапія, імунокорекція.

Ключевые слова: осложнения беременности, вспомогательные репродуктивные технологии (ВРТ), озонотерапия, иммунокоррекция.

Key words: complications of the pregnancy, assisted reproductive technology (ART), ozone therapy, immunocorrection.

ВСТУП. Перебіг вагітностей, що наступили в результаті лікування безпліддя методами ДРТ, характеризується високою частотою ускладнень, зокрема загрозою переривання вагітності (75 \%), передчасними пологами (30 \%), невиношуванням (45\%), плацентарною дисфункцією (60\%) [1-5]. Незважаючи на існуючі методи лікування і профілактики ускладнень вагітності, недостатня увага приділяється етіопатогенетичним чинникам розвитку гестаційних ускладнень після ДРТ, зокрема імунологічним факторам та проблемам ангіогенезу [6-10]. Тому пошук нових методів лікування і профілактики, направлених на зменшення ускладнень вагітності після ДРТ, залишається актуальним у сучасному акушерстві [11].

Метою роботи стало зниження частоти ускладнень вагітності в жінок після застосування ДРТ шляхом оптимізації патогенетичних підходів до їх лікування й профілактики з використанням озонотерапії та імунокорекції.

МАТЕРІАЛИ ТА МЕТОДИ. ВідПовідНо до Поставленої мети було обстежено 120 вагітних, з них 90 жінок, що завагітніли після лікування безпліддя методом ДРТ, які були розподілені на 2 клінічні групи. До першої клінічної (основної) групи увійшли 45 жінок, яким проводилося комплексне лікування ускладнень вагітності за допомогою озонотерапії та імунокорекції. До другої клінічної групи (групи порівняння) увійшли 45 жінок, у яких ведення вагітності здійснювалося за загальноприйнятою методикою підтримки періоду гестації після застосування ДРТ. Групу контролю склали 30 вагітних жінок, які самостійно завагітніли, не мали в анамнезі неплідності та з фізіологічним перебігом вагітності.

Усім вагітним проведено клінічне, ультразвукове та доплерометричне обстеження, гормональні дослідження включали вивчення рівнів і динаміку вмісту ХГЛ, естрадіолу, прогестерону, кортизолу, плацентарного лактогену в сироватці крові імуноферментним методом. Імунологічні дослідження включали визначення кількості загальних Т-лімфоцитів, Т-хелперів, Т-супресорів, В-лімфоцитів і природних кілерів, рівня ЦІКта імуноглобулінів основних класів G, А, М у сироватці крові. Проведено вивчення вмісту в сироватці крові інтерлейкінів (IL-1P, IL-2, IL-6, IL-8, IL-10), фактора некрозу пухлини (ФНПа), розчинного Fas-ліганду, концентрацію ендотеліну-1 (ЕТ-1) та судинно-ендотеліального фактора росту (VEGF). Вагітним обстежених груп проводили гемостазіологічні дослідження, оцінювали значення таких показників, як: протромбіновий індекс (ПІ), тромбіновий час (ТЧ), активований частковий тромбопластиновий час (АЧТЧ), активований час рекальцифікації (АЧР), фібриноген, рівень Д-димеру.

Лікування вагітних у групі порівняння проводилося за стандартною методикою підтримки вагітності після ДРТ. В основній групі додатково призначалися ректальні супозиторії азоксімера броміду протягом 10-14 діб у комплексі з озонотерапією (внутрішньо- 


\section{Акушерство та гінекологія}

венне введення медичного озону через добу, 10 разів на курс лікування) за допомогою апарата «Озон УМ-80» (Україна).

Статистична обробка результатів досліджень проводилася на персональному комп'ютері 3 використанням параметричних та непараметричних методів варіаційної статистики за допомогою прикладного програмного забезпечення «Statistica» (StatSof, 2006).

РЕЗУЛЬТАТИ ДОСЛІДЖЕННЯ ТА ЇХ ОБГОВОРЕННЯ. Середній вік жінок після використання ДРТ склав: основної групи - 33,4 $\pm 3,8$ року, контрольної

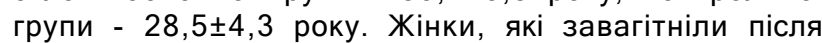
застосування ДРТ, були більш старшого віку (>30 років), статеве життя розпочинали до 18 років, мали обтяжений акушерський і гінекологічний анамнез, перенесли запальні та інфекційні захворювання статевих органів, оперативні втручання на органах малого таза, мали неодноразові намагання завагітніти методами ДРТ.

До основних прогностичних критеріїв несприятливого перебігу вагітностей після застосування ДРТ відносяться зміни, які визначаються вже в перші 68 тижнів вагітності: невідповідність КТРта середнього діаметра плідного яйця терміну гестації, порушення ЧСС ембріона, збільшення судинного опору в маткових та спіральних артеріях, наявність ретрохоріальної гематоми, зниження рівнів р-ХГЛ, прогестерону $(29,3 \pm 3,1$ нг/мл), естрадіолу (7,8 $\pm 1,2$ нг/мл) $(P<0,05)$.

Порушення імунного статусу спостерігалося у

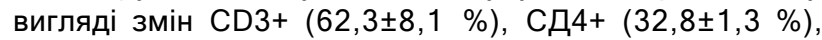
ЦІК, дисімуноглобулінемії, підвищенні NK, дисбалансу фагоцитарної активності нейтрофілів, активізації прозапальних інтерлейкінів IL-1 $(62,5 \pm 4,7$ пг/мл), IL-

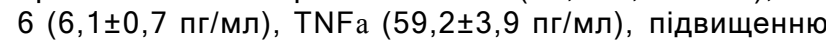

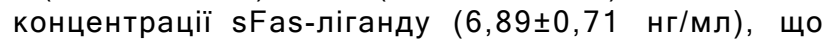
сприяє в подальшому розвитку ускладнень гестаційного процесу.

У вагітних після застосування ДРТ мають місце гемостазіологічні розлади, підвищення VEGF

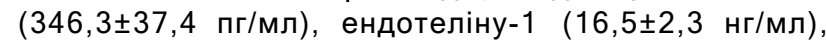
зменшення нітритів $(0,77 \pm 0,03$ мкмоль/л) та сполучення нітратів і нітритів $(25,4 \pm 1,1$ мкмоль/л), що свідчить про існуючі проблеми неоангіогенезу, імплантації та розвитку плідного яйця.

Отримані результати обстеження жінок з ускладненнями після застосування ДРТ були розцінені як показники порушення ангіогенезу з подальшим розвитком ендотеліальної дисфункції та порушенням імунологічного статусу, що призвело до клінічних проявів загрози переривання вагітності, розвитку плацентарноїдисфункції, синдрому затримки росту плода.

В основній групі через 2 тижні від початку лікування позитивно змінювалися імунологічні показники, цитокіновий профіль $(p<0,05)$. Звертає на себе увагу значне зменшення рівнів ЕT-1 (2,6 $\pm 0,7$ нг/мл) та VEGF (78,3 $\pm 12,5$ пкг/мл), що свідчило про нормалізацію функції судин, відновлення локальної гемодинаміки, підтверджене доплерометричними дослідженнями. Відсутність сегментарних скорочень та ретрохоріальної гематоми у 82,2 \% жінок основної групи на відміну від групи порівняння (22,2 \%) вказує на високу ефективність комплексного лікування ускладнень вагітності після ДРТ.

Дані про завершення вагітності в жінок обстежених груп продемонстрували, що в результаті проведення запропонованой корекції в основній групі вдалося знизити частоту самовільного переривання вагітності до 4,5 \% проти 11,1 \%в групі порівняння $(\mathrm{P}<0,05)$. Це дало можливість зафіксувати частоту термінових пологів на рівні 84,4 \%, що наближалося до показників у контрольній групі - 96,7 \%, і було вище, ніжу групі порівняння - 57,8 \% $(P<0,05)$. Застосування патогенетичної терапії також дозволило знизити загрозу переривання вагітності в 3,5 раза, прееклампсію - в 3 рази, плацентарну дисфункцію - в 2,8 раза, затримку росту плода - в 2,4 раза.

Важливим показником ефективності запропонованого комплексу профілактики та лікування ускладнень вагітності та пологів після застосування ДРТ $є$ оцінка стану новонароджених. При аналізі стану новонароджених за шкалою Апгар оцінку 7-10 балів в основній групі отримали 88,4 \% дітей, що наближалося до контрольної групи - 96,7 \% і було вищим, ніж у групі порівняння - 70 \% $(\mathrm{P}<0,05)$. При аналізі маси тіла новонароджених, що народилися від матерів обстежених груп, було виявлено, що в основній групі 3 масою більше 3000 г народилося $67,4 \%$ дітей, що вище, ніжу групі порівняння - $45 \%$ дітей $(\mathrm{P}<0,05)$.

Аналізуючи результати перебігу вагітностей та пологів у жінок обстежених груп, а також стан новонароджених, можна зробити висновок, що завдяки запропонованому комплексу лікування й профілактики ускладнень вагітності 3 використанням озонотерапії та азоксімера броміду для своєчасної патогенетичної корекції доклінічних змін показників, що вивчалися, вдалося покращити перебіг вагітностей, отриманих після застосування ДРТ, зменшити частоту можливих ускладнень вагітності й пологів і знизити кількість перинатальної захворюваності та смертності.

ВИСНОВКИ. 1. В основі етіопатогенезу ускладнень вагітності, отриманої після ДРТ, лежать зміни імунної, ендокринної, гемокоагуляційної, ендотеліальної систем. Діагностично значимими факторами ризику ускладненого перебігу вагітності після ДРТ $€$ доклінічні зміни ультрасонографічних показників, гормональні та імунологічні розлади, патологічні зміни коагуляційної ланки гемостазу, ендотеліальна дисфункція та оксидативний стрес.

2. Використання медичного озону та імуномодулятора (азоксімеру бромід) дозволяє нормалізувати імунологічні зсуви, ендотеліальну дисфункцію, порушення гемостазу, оксидативний стрес, підвищити частоту доношування вагітності після використання ДРТ, достовірно покращити її перебіг, якісно зменшити кількість ускладнень та перинатальних втрат.

ПЕРСПЕКТИВИ ПОДАЛЬШИХ ДОСЛІДЖЕНЬ.

Перспективними є подальші генетичні дослідження, які впливають на розвиток ендотеліальної дисфункції у вагітних після застосування ДРТ. 


\section{Акушерство та гінекологія}

\section{СПИСОК ЛІТЕРАТУРИ}

1. Жук С. И. Проблемы невынашивания беременности после экстракорпорального оплодотворения / С. И. Жук // Здоровье женщины. - 2006. - № 2. - C. 40-43.

2. Серова О. Ф. Новые аспекты генеза ранних репродуктивных потерь / О. Ф. Серова, Н. В. Зароченцева, С. Ю. Марченко // Журнал акушерства и гинекологии. - 2011. - № 4. - С. 11-16.

3. Сидельникова В. М. Невынашивание беременности / В. М. Сидельникова, Г. Т. Сухих. - М. : ООО «Медицинское информационное агентство», 2010. - 536 с.

4. Стрижаков А. Н. Потеря беременности А. Н. Стрижаков, И. В. Игнатко. - М. : ООО «Медицинское информационное агентство», 2007. - 224 с.

5. Ford H. B. Recurrent pregnancy loss: etiology, diagnosis and therapy / H. B. Ford, D. J. Schust // Rev. Obstet. Gynecol. - 2009. - Vol. 2, № 2. - P. 76-83.

6. Волкова Л. В. Клинико-диагностическое значение сосудисто-эндотелиального фактора роста при неудачных попытках ЭКО / Л. В. Волкова, О. С. Аляутдина // Акушерство и гинекология. - 2011. - № 4. -С. 126-129.
7. Павлов К. А. Фетоплацентарный ангиогенез при нормальной беременности: роль сосудисто-эндотелиального фактора роста / К. А. Павлов, Е. А. Дубова, А. И. Щеголев // Акушерство и гинекология. - 2011. - № 3. - С. 11-16.

8. Шмагель К. В. Иммунитет беременной женщины / К. В. Шмагель, В. А. Черешнёв. - М., 2003. - 226 с.

9. Guzeloglu-Kayisli $O$. The role of growth factors and cytokines during implantation: endocrine and paracrine interactions / O. Guzeloglu-Kayisli, A. Kayisli, H. S. Taylor // Seminars in reproductive medicine. - 2009. - Vol. 27, № 1. - P. 62-79.

10. Slavik L.The pathophysiology of endothelial function in pregnancy and the usefulness of endothelial markers / L. Slavik, J. Prochazkova, M. Prochazka // Biomed. Pap. Med. Fac. Univ. Palacky Olomouc Czech. Repub. - 2011. - Vol. 155. - P. 1-5.

11. Алехина С. П. Озонотерапия: клинические и экспериментальные аспекты / С. П. Алехина, Т. Г. Щербатюк. - Н. Новгород, 2003. - 240 с. 